\title{
Democracy And Good Governance In Relation To Development And Underdevelopment: Africa's Experience
}

\author{
Tandu, Egbe Ojong (Ph.D) Tandu, Mary Anyie (M.Ed) \\ Department Of Political Sciencecollege Of Educationakamkpa Cross River State
}

\begin{abstract}
Today's approach to democracy in Africa is very far from what is desired and the consequence is that good governance had been sacrificed on the altar of mediocrity. This has led to the collapsed of some democracies in Africa making development in Africa looks like an impossible task. We had rather seen underdevelopment enthroned almost everywhere in the continent thereby strengthening dependency in Africa. This has become worrisome. The paper adopts as its methodology historical/descriptive and prescriptive approaches. The paper therefore attempts to operationalize the concepts: Democracy, Good governance, development and underdevelopment to give the reader a leeway to understand the main trust of the paper. The thrust of this paper therefore is to examine Democracy and Good governance in relation to Development and Underdevelopment: Africa's experience. Finally, the prognoses.
\end{abstract}

Key words: Democracy, Good Governance, Development and Underdevelopment.

\section{INTRODUCTION}

Democracy remains the best option to bring about good governance and to also provide a good atmosphere for growth and development in Africa. Developing countries and Africa in particular cannot ignore democracy and its institutions if they have to achieve development and more importantly sustainable development. Democratic institutions are neither limited or peculiar to America and Europe but are also relevant, appropriate and significant to Africa. The conflict between democracy, good governance and development in Africa is not a phenomenon which is perculiar to Africa but it has to do with the mine set of our leaders who seem to missed the purpose of leadership. The attitude of African leaders over the years has not help us in putting in place true democracy and good governance for development. This shall become more glaring as we proceed with the discourse.

\section{OPERATIONALIZATION OF CONCEPTS}

\section{A. DEMOCRACY}

The word Democracy has been conceptualized by many schools of thought and scholars in different ways but yet their general perception seems to marry and gear towards the same idea, that is, "collective will and majority decision". Democracy is derived from two Greek words 'demos' (People) and 'cratia' (power) meaning power of the people. Lincoln cited from Dictionary of political science $1^{\text {st }}$ Edition 2006 defined it as "the government of the people, by the people and for the people". Political equality, tolerance, popular sovereignty, and change of government through constitutional means are all basic principles of democracy.

\section{B. GOOD GOVERNANCE:}

Politicalscientists have viewed the concept of governance as not being a new expression in the literature of political science. However, the attempt to make conceptual use of the expression was made popular in literature on African development by the World Bank Publication on Sub-Sahara Africa titled "From crises to sustainable Growth" (1992). In this report African political and economic problems were seen from the perspective of crises of governance. From the perspective of this study Good governance is seen as the fundamental process by which the lives and dreams of the people are jointly pursued, by deliberate and systematic strategies and policies, for the attainment of their maximum potentials. It is the combination of responsible leadership and enlightened public participation. Politically, governance is seen to mean the management of the people in a systematic, organized way for the best possible results. In the light of the above definition, governance is not restricted to political institutions alone as it would have been envisaged but also indeeds other spheres of human endeavour.

Akanbi (2004) on the other hand defined good governance to mean government that incorporates the future of accountability of public officials, transparency in government procedures and processes, reliable flow of information to the citizenry, freedom of the press and adherence to the rule of law. 


\section{DEVELOPMENT}

The concept of developmentfrom a collective viewpoint is a multidimensional concept. People see it differently depending on their viewpoint. For the purpose of this study, we adopted the following in order to operationalized the concept. From the point of view of Rodney (1969) it is "a many sided process. At the level of the individual it implies increase skills and capacity, gender freedom, creativity, self-discipline, responsibility and material well-being. One thing which could be derived from this forgoing definition is that development goes beyond economic growth or indicators. Todaro (1985) on the other hand defined it as "a multidimensional process involving the re-organization and re-orientation of the entire economic and social system. This involves, in addition to improvement of income andoutput, radical changes in institutional, social and administrative structures as well in popular attitudes, customs and beliefs". The main contention of Todaro is that development is both a physical process and a state of mind. The transformation of institution is one aspect. The other aspect is that the thinking of the people must change.

In his contribution to the meaning of development Seers (1969) argues that: The question to ask about a country's development are therefore; what has been happening to poverty? What has been happening to unemployment? What has been happening to inequality? If all three of these have declined from high levels, then beyond doubt this has been a period of development for the country concerned. If one or two of these central problems have been growing worse, especially if all three have, it would be strange to call the result development, even if per capita income doubled". Seers definitionis important for an understanding of development because it is centred on the improvement in the living condition of the individual. By implication, it means that the economy could grow without developing.

\section{UNDERDEVELOPMENT}

This is not absence of development at all, becauseevery society has development in one way or another and to a greater or lesser extent. Underdevelopment is a situation where a society is lagging behind in terms of standard of living, life expectancy, education and technology,industrialization, health facilities etc. Underdevelopment makes sense only as a means of comparing level of development. It is very much tied to the fact that human social development has been uneven and some societies have advanced further because of their culture and circumstance. Both development and underdevelopment are aspects of the same phenomenon historically simultaneous, both are linked functionally and therefore, interact and condition each other mutually. This results in the division of the world between industrialized, advanced, or "central" countries and backward or "peripheral" countries. This situation accentuate dependency which is a situation in which a certain number of countries have their economy conditioned by the development and expansion of another placing the dependent countries in a backward position exploited by the dominant countries. Sunkel and Pedropaz cited from Timamy, 2007.

It is our belief that the creative capacity of human beings is the driving force of the development process. What makes development or underdevelopment happen is our ability to or not to imagine, theorize,conceptualize, experiment, invent, articulate, manage, solve problems, and do a lot of other things with our mines and hands that contribute to the progress of individual and the state. Natural resources, climate, market size, governmental policies and many other factors influence the direction and pace of progress, but the engine is human creative capacity. What follows is the chronicle of African leaders attitudes in governance that have resulted in development and underdevelopment in Africa respectively.

\section{THE DISCOURSE}

Democracy gives us an opportunity to put in place leaders and not just leaders but good and committed leaders. The kind of leaders that emerged through a free and fair process where the people vote their best after good assessment. In Africa, those who emerged as leaders in most cases are not good and committed people who have vision, and sound sense of judgement with impeccable character. Good governance comes from leadership that is popular and that pursues the live and dreams of the people joinedly through deliberate and systematic policies and strategies for the attainment of the dreams of the people and the state. It is the combination of responsible leadership and enlightened Public participation that brings about goodgovernance.

African leaders made a bold attempt to turn around their development fortunes by adopting in July 1979, the Monrovia strategy and in April 1980 the Lagos Plan of Action (LPA) for the economic development of Africa, 1980-2000 and the Final Act of Lagos. The LPA was a visionary, far reacting and unprecedented blueprint on how to foster collective self-reliance and sustainable development of the continent. Subsequent attempts at charting Africa's development have drawn inspiration from the visionary framework. Despite these efforts, Africa remains the poorest and economically marginalized in the world because of lack of commitment beyond paper work by the leaders (Africa's ministerial council of science and Technology,2003). Akey allenge to the realization of the vision and goals articulated in the LPA and subsequent socio-economic development 
framework has been that of implementation of specific policies and programmes. The continent has continued to rely on external financial support often targeting short-term activities and solutions. In this respect, science, technology and innovation have not been given serious attention as engines of long-term development. This is demonstrated by, for example low and declining public expenditure on Research and Development (R\&D) in most countries as well as weak institutions on the other hand. Research results of public R \& D activities do not often get accessed and used by local industries. In many cases there is mismatch between R \& D initiatives and national industrial goals and strategies.

African leaders depend so much on foreign indused development strategies. For instance, according to Ogbuago, (2006) starting from the late 1950s when Nigeria gained self governing status from Britain preparatory to full independence in 1960, the leaders seem to have asked themselves a basic question. What should be done given Nigeria's situation to achieve economic development? In attempting to answer this question Nigerian leaders decided to undertake joint ventures with foreign investors. This calculation was that with time the local people through this economic association would acquire the necessary technological skills and knowledge to stand on their own. For the sake of emphasis the premise for this approach was that for the development of economic sector to be successful it will depend largely on the volume of foreign capital, skills, technology, and managerial manpower and technical flow into the country. The point to be made here is that not even one, country in Africa that have accepted foreign induced development strategy had come out of it smiling.

Education and training investment in Africa is still low. At a minimum "Leapfrogging", as the Japanese have done requires a massive investment in education and research. Who would undertake that investment in Africa? Everywhere in Africa during the transitional years, schools tended to provide a classical education emphasizing basic administrative and literally skills rather than the training of skilled labour, engineers, chemists, managers, and accountants needed by industry (Mytelka 1984). This pattern, supplemented by training in thepure sciences, persisted well into the post independence era and contributed to the lack of integrations between what can be called the knowledge production and the goods production sector (Cooper 1974). One would be hard put even to find universities in sub-Saharan Africa offering majors in such fields as textile or petroleum engineering and the training of skilled workers and line supervisors through post primary vocational schools remains seriously deficient (Lall, 1987). Africa's low investment in science and technology education is declining. The continent is also loosing some of its best scientific and technological expertise to other regions of the world. In many countries of Africa infrastructure for Research and Development (R \& D) has been neglected and is decaying. The educational institution particularly universities and technical colleges are in urgent need of renewal after many years of neglect and disorientation from local and national priorities.

African leaders attitudes toward governance have thrown up the problem of Brian-Drain that had affected the development of the continent. For instance, while decrying the brain-drain phenomenon in Africa as regards the health sector, the world health organization survey of 1998 of seven African countries revealed that the public health sector lost in Ghana about 72.9\%, Lesotho, 7.6\% and Malawi, 52.9\% of doctors to other parts of the world (WHO, 2003).

African countries adopted import reproduction instead of import substitution. Import reproduction strategies such as those implemented in Africa take "product" as their point of departure instead of "purpose". They thus ignore the extent to which product incorporate concepts of functionality, cost, quality and aesthetics that correspond to the producers' principles market of sale. An import substitution strategy reverse this process by first identifying the purpose embodied in imported products then determining their relevance to the local environment and lastly designing a product that conforms most closely to domestically available inputs, material and non-material (Mytelka, 1989). He stated further that, not only the practice of import substitution different from that of import reproduction, but it technology differs as well. Thus, in a process of import substitution "production" is not the sole end. Rather it became part of a more process of technology learning and encompasses product specialization and mastering becomes part of the process of technological development and a basis for development in every ramification. In contrast to import substitution, import reproduction adopted by African leaders shift our attention away from these dynamics learning effects and rather creates technological underdevelopment of the continent.

Lack of encouragement of local technicians and their techniques by African states/government. There is a weak link between the African states and their societies and this has not encouraged the local technicians and their techniques to grow. Steward, (2001), pointed out that the development of local technical capacity is another condition which allows for the production of more appropriatemachines. She stressed that, what is needed above all is local technical innovation directed towards local needs. But the problems with African countries have to do with the government lack of interest and unwillingness to commit finances for the needed strategies that will propel development in Africa. Bazaar mentality of African leaders have starved the continent of the necessary funds for development. African leaders spend so much time and money on state bouquets and celebrations that does not contribute to development of their countries. The governments are always over 
bloated because they have to give the boys jobs in government. These boys assist them to get into office unconventionally. This deprived the states of the much needed funds to finance developmental programmes.

Corruption is the bane of Africa's development. Our leaders are not sincere. They are very dubious in almost every of their intention. Public funds lined up private pockets and our finances are taken abroad into private bank accounts. We have had situations where some leaders were richer than their countries. The Nigerian government is still pursing Late General Sani Abacha's loot in foreign banks. Peace and Security:Government is suppose to provide peace and security for the people. When peace and security is provided people will have free and peaceful atmosphere to invest and be able to recover their investments and also make profit. Some African states established and developed the entire paraphernalia of a modern democratic political system and yet their leaders failed to maintain law and order effectively. The leaders show helplessness or limitations in thoroughly eliminating such elements that threatened peace and security in their states. This has affected investments both locally and from outside which could have propel the needed development in their states. There is so much disparity between the rich and the poor. The judiciary had failed to take it's rightful place to dispense justices Nigeria is a typical example. Elections in Africa: Elections are very important in any democratic dispensation. One man one vote and the vote must have value.In Africa elections are almost meaningless. African votes have no value because the votes do not count and the do not matter. After elections the poor are left out in the scheme of things. This throws up a lot of problems. For instance, militancy and insurgency as we see in most African countries. Nigeria, Lybia, Egypt to mention a few are examples. This scenario presented above can not in any way encourage development in Africa. What is presented here as the bane of Africa's development arising from poor governance is not exhaustive but a tip on the iceberg.

\section{CONCLUSION}

Arising from the above analysis, it can be concluded that the only antidote to democratic sustenance is good governance at all levels. The moment this is established, it will be easier for nation-states in Africa to focus their energies and resources on meeting the challenges of growth and development, security and creative existence for the continent. The importance of having committed African leaders which is the responsibility of the entire continent, is a prerequisite. And if democratic principles are distorted, misdirected, deceptive and nontransparent then danger looms in the continent of Africa.

\section{PROGNOSES}

Development must be seen as a national issue, a problem of transforming domestic, social, economic and political structures by African leaders. Emphasis must be on our self- reliance development at a national level and to collective self-reliance and autonomy within the world. All African countries must reorganize the societies to reflect good government that is genuine popular, honest, dedicated, selfless leadership which see their destiny as that of the poor majority. It is only when Africa employ unvaried looking strategies and develops sound independent national economicsthat they can participate in the global system as equals.

African countries should de-emphasize technologytransfer which has been too slow to come and rather integrate science, technology and engineering into their national planning schemes. Since technology cannot be transferred, the way out is to emphasize research and development (R \& D) covering basic and applied research, to train first class scientists, technologist, engineers, and to motivate them to stay and work in Africa, after ensuring that there is massive improvement in our educational standards.

Infrastructural decay in the form of dry water pipes, unreliable communication system whose price continues to escalate by the day despite its malfunctioning, epileptic or fluctuating energy supply like noticed in Nigeria which have tended to compound the problem of development must be frontally addressed. Africa eaders must maintain programmes that anchor on the determination of Africans to extricate themselves and the continent from the malaise of underdevelopment and exclusion in a globalizing world. To attain development therefore, democracy and good governance must be taken seriously. Men and women who are incorruptible, with sound principles and sound intellectual calculation laced with creativeness should be considered as leaders. Avoiding underdevelopment tendencies is embracing developmental strategies that require that we live in our world in such a way that either we do not become poorer in the future or we do not live in such a way that the negative effects of what we do now will affect future generations. 


\section{REFERENCES}

[1] African Ministerial Council of Science and Technology Report (AMCOSTR). 2003.

[2] Akanbi, T. N. (2004). The theory of economic growth. Homewood: Richard D. Lrwin, Inc.

[3] Azeez, E. A. (2002). Development and underdevelopment. London, Longman.

[4] Chaturvedi, A. K. (2006). Dictionary of Political Science. Nigerian/India: Academic Publishers.

[5] Cooper, F. (1994). "Africa and the world Economy" Africa studies Review 2/3 (June/September) 1-86.

[6] Lall, S. (1989). Long-term Perspective in sub-saharan Africa Draft Background Paper of Industry. World Bank: Special office for Africa Affairs. May.

[7] Mytelka, L. K. (1989). The unfulfilled promised of African industrialization. African studies Reviewed. Vol. 32. No. 3. Pp 77-137.

[8] Ogbuago, C. (2006) Lecture notes on political Economy of Nigeria. Unpublished.

[9] Rodney, W. (1972). How Europe underdeveloped Africa. London. Bogle-L'ouverture publications.

[10] Seers, T. (2000). Development - Underdevelopment: The Political Economy of Inequality London. Longman.

[11] Steward, E. (2001). Technology and underdevelopment. London. Macmillan Press.

[12] Timamy Khalil, M. H. (2008). The Political Economy of Technological Underdevelopment in Africa (Renaissance, Prospects, Global Tyranny, and Organized spoliation). Nigeria Concept publications.

[13] Todaro, M. P. (1985). Economic for A developing world. London. Longman.

[14] World Bank (1992). World Development Report. New York. Oxford University Press.

[15] World Health Organization (2003) WHO Survey of 1998 of seven African countries. WHO. 2003. 